\title{
JAKOŚĆ ENERGII ELEKTRYCZNEJ W LINIACH ZASILAJĄCYCH ODBIORNIKI PKP PLK S.A.
}

\begin{abstract}
Artykuł prezentuje definicje wynikające $\mathrm{z}$ aktualnych uwarunkowań prawnych i technicznych. Przedstawiono również problemy związane z jakością energii elektrycznej w podstacjach trakcyjnych w czasie pracy awaryjnej. Stan awaryjny powoduje nieregularności, które skutkują występowaniem zakłóceń wprowadzanych do sieci zasilającej i odbiorów zasilanych z podstacji trakcyjnych. Ponadto, przedstawiono wpływ występowania harmonicznych prądu na pracę wybranych odbiorów energii elektrycznej, jak również metody jego ograniczania. Wymieniono podstawowe wymagania co do jakości energii elektrycznej w PKP PLK S.A.
\end{abstract}

Słowa kluczowe: podstacja trakcyjna, harmoniczne prądu, zespół prostownikowy.

\section{Wprowadzenie}

Wyższe harmoniczne prądów i napięć $[1,3,8,9]$ są przyczyną dużych strat energetycznych. Powodują także uszkodzenia w urządzeniach elektrycznych i elektronicznych. Wprowadzane są coraz bardziej restrykcyjne zapisy norm, które zmuszają firmy dystrybuujące energię elektryczną oraz odbiorców do ograniczania zaburzeń wprowadzanych do sieci energetycznej $[1,5,8,9,10]$. Urządzenia generujące wyższe harmoniczne powodują nieprawidłowe działanie innych urządzeń (rys. 1) i w konsekwencji mogą spowodować ich uszkodzenie. Powstające zniekształcenia napięciowe zależne są od parametrów układu zasilania, a zniekształcenia prądowe są zależne od indywidualnych cech danego urządzenia.

\footnotetext{
${ }^{1}$ Robert Żelazny, PKP Polskie Linie Kolejowe S.A. oraz Politechnika Częstochowska Wydział Elektryczny, email: Robert1980@interia.eu
} 


\section{Jakość energii elektrycznej w podstacjach trakcyjnych}

Podstacje trakcyjne (PT) są jednym z większych odbiorów przyłączonych do systemu elektroenergetycznego. Urządzenia podstacji trakcyjnych składają się z dwóch części: przemiennoprądowej i stałoprądowej. System przemiennoprądowy służy przede wszystkim do zasilania urządzeń (PT) oraz do zasilania odbiorów nietrakcyjnych, a system stałoprądowy zasilany przez zespoły prostownikowe (rys. 2) służy do zasilania sieci trakcyjnej. Kolejowy system elektroenergetyczny jest zbudowany w taki sposób, aby poprzez linie zasilające i urządzenia podstacji trakcyjnych zasilać pojazdy trakcyjne napięciem $3000 \mathrm{~V}$ prądu stałego. Dodatkowo system ten z części przemiennoprądowej zasila odbiory kolejowe. Dopuszczalna wartość odkształcenia prądu zależy od grupy przyłączeniowej, do jakiej dany odbiorca jest zakwalifikowany [5, 8, 9, 10]. W związku $\mathrm{z}$ brakiem $\mathrm{w}$ polskim prawodawstwie przepisów regulujących zawartość wyższych harmonicznych prądu w sieciach SN oraz WN, dla porównania zmierzonych wartości harmonicznych można posłużyć się postanowieniami normy IEEE Std 519-2014 [1].

W celu obliczenia poziomów zawartości harmonicznych w odkształconych przebiegach napięć i prądów (rys. 5, 9) wprowadzono pojęcie „całkowitego współczynnika odkształcenia harmonicznych" THD (ang. Total Harmonic Distortion), w dalszej części pracy są stosowane oznaczenia zgodne z normą IEEE 1459-2010 [2]. Współczynnik THD oznacza wartość całkowitej zawartości harmonicznych napięcia i prądu:

$$
\begin{gathered}
T H D u=\sqrt{\left(\frac{U}{U_{1}}\right)^{2}-1}=\sqrt{\sum_{h \neq 1}\left(\frac{U_{h}}{U_{1}}\right)^{2}} \\
T H D i=\sqrt{\left(\frac{I}{I_{1}}\right)^{2}-1}=\sqrt{\sum_{h \neq 1}\left(\frac{I_{h}}{I_{1}}\right)^{2}}
\end{gathered}
$$

gdzie: $U$-wartość skuteczna napięcia

$U_{1}$ - wartość skuteczna pierwszej harmonicznej

$U_{\mathrm{h}}$ - wartość skuteczna h-tej harmonicznej

I- wartość skuteczna prądu

$I_{1}$ - wartość skuteczna pierwszej harmonicznej

Ih - wartość skuteczna h-tej harmonicznej 


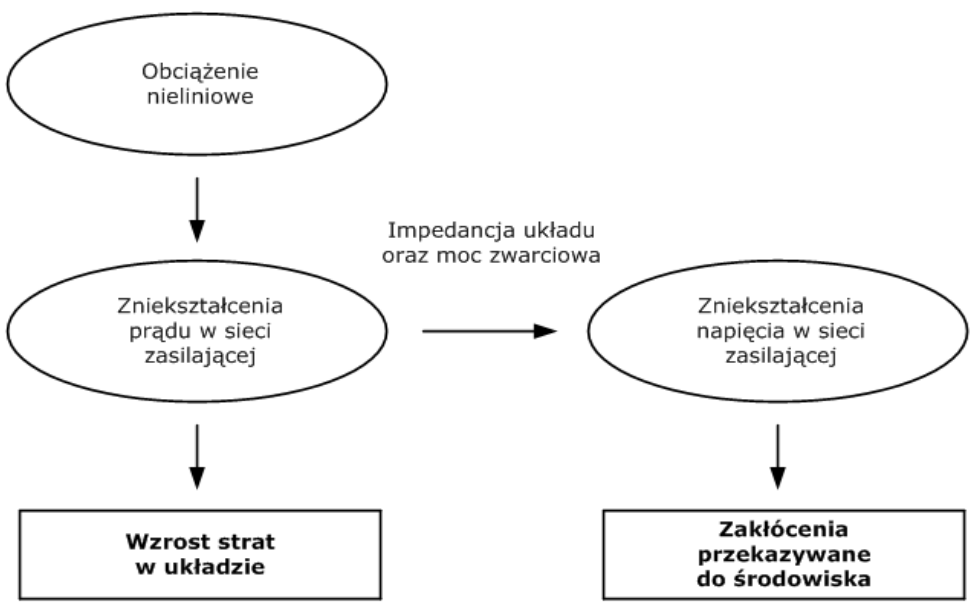

Rys. 1. Odbiornik nieliniowy źródłem zniekształceń harmonicznych prądu, który powoduje zniekształcenia napięcia w sieci zasilania

Fig 1. Non-linear receiver sources of current harmonic distortion, which causes voltage distortion in the power supply

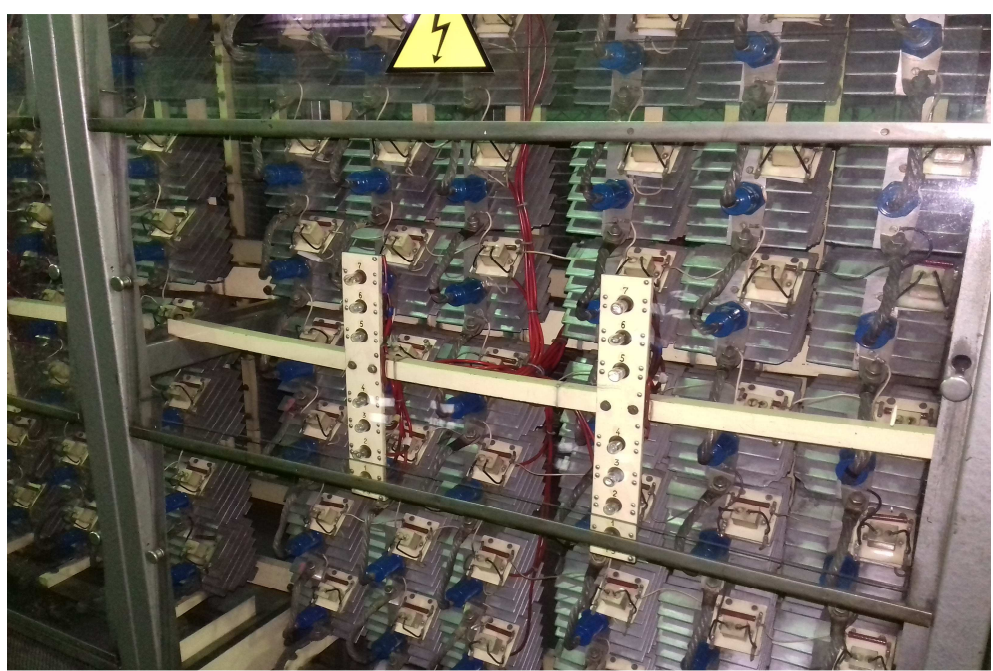

Rys. 2. Zespół prostownikowy typu PK 17/3,3-3, o danych znamionowych: prąd $1700 \mathrm{~A}$, napięcie wyjściowe $3300 \mathrm{~V}$. Prostownik z zastosowanym typem diod D200/1200. Liczba diod w zespole 288 sztuk

Fig 2. PK 17 / 3,3-3 rectifier unit with nominal data: current $1700 \mathrm{~A}$, output voltage 3300 V. Silicon rectifier with diode type D200 / 1200. Number of diodes in 288 units 
Urządzenie pomiarowe PQM 701Z podłączone zgodnie z rys. 3 .

Wykonano pomiary na podstacji trakcyjnej zgodnie z niżej opisanymi danymi:

\section{Pomiar 1}

Zasilanie podstacji trakcyjnej napięciem $20 \mathrm{kV}$ poprzez linię zasilającą.

Pomiar napięcia przez przekładniki napięciowe $20000 \sqrt{3} 100 \sqrt{3}$ [V]

Pomiar prądu przez przekładniki prądowe 200 / 5 [A]

\section{Pomiar 2}

Pomiar napięcia przez przekładniki napięciowe $6000 \sqrt{ } 3100 \sqrt{ } 3$ [V] (rys. 4)

Pomiar prądu przez cęgi prądowe przyrządu PQM $701 Z$ [A]

\section{Pomiar 3}

Pomiar napięcia bezpośrednio [V]

Pomiar prądu przez cęgi prądowe przyrządu PQM 701Z [A]

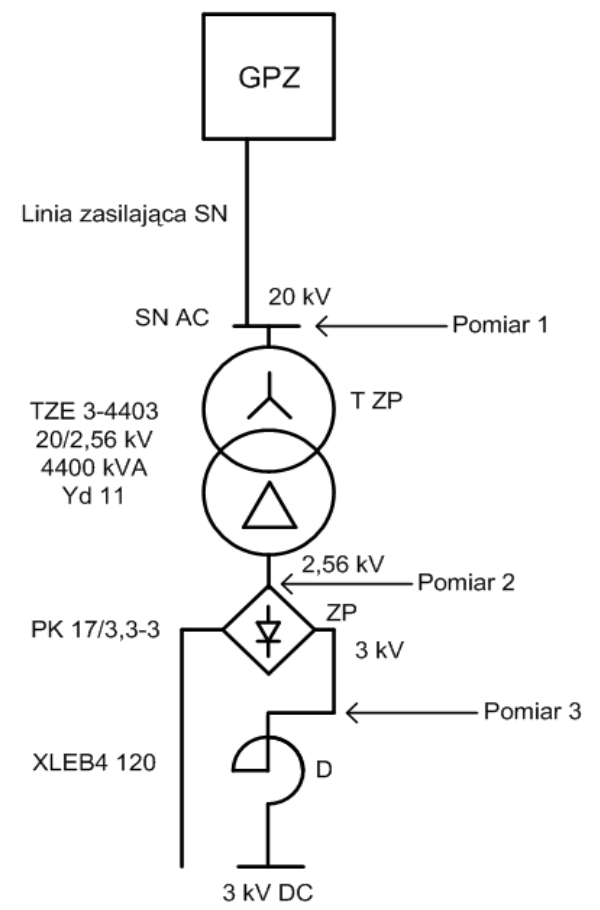

Rys. 3. Schemat ideowy podstacji trakcyjnej

Fig 3. Schematic diagram of the traction substation 


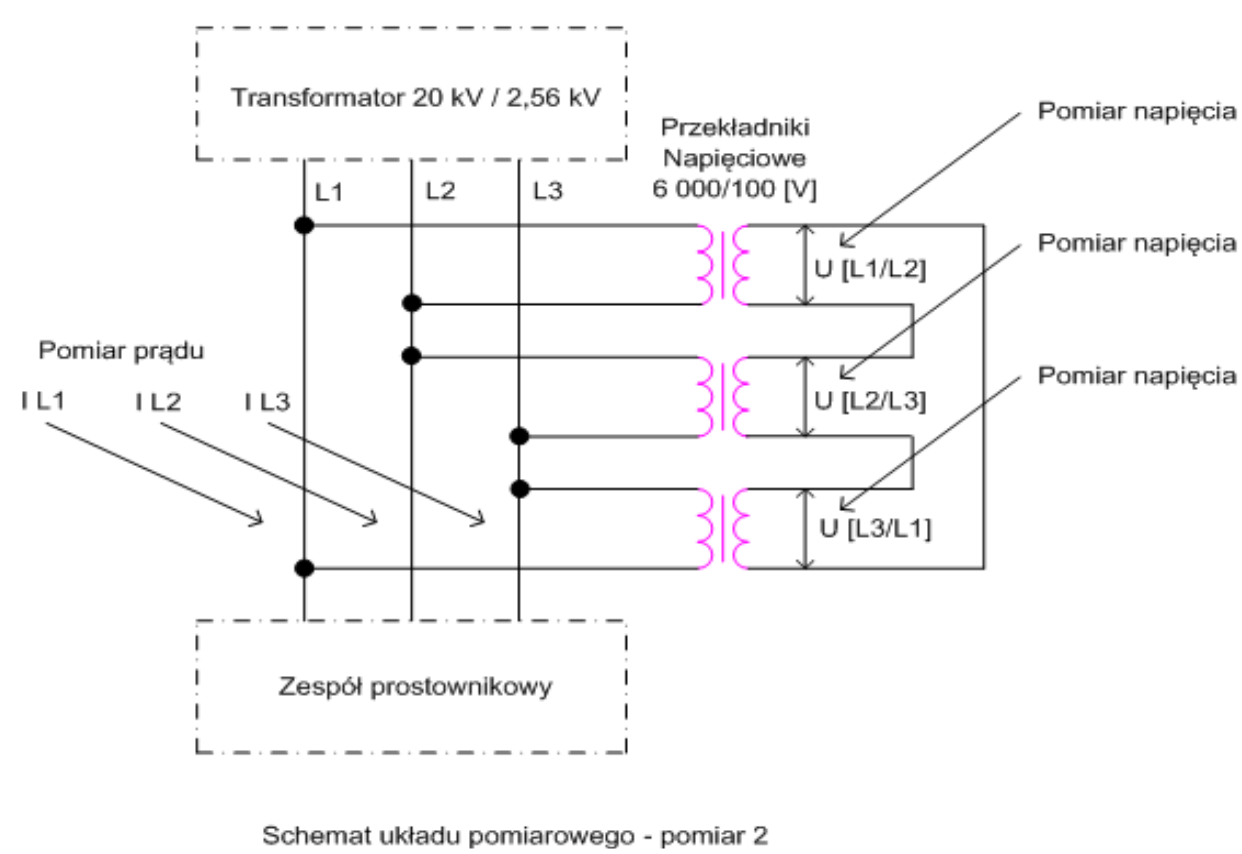

Rys. 4. Schemat podłączenia przekładników napięciowych - pomiar 2

Fig 4. Connection diagram of voltage transformers - measurement 2

Analizując wyniki pomiarów stwierdzono, że zawartość wyższych harmonicznych prądu, podczas awaryjnej pracy podstacji trakcyjnej, znacznie przekracza dopuszczalne wartości określone w dokumentach normatywnych. Awaryjna praca podstacji trakcyjnej polega na tym, że po uszkodzeniu elementów urządzenia wygładzającego, nastąpiło jego odłączenie przez obsługę w rozdzielni 3000 $\mathrm{V}$ prądu stałego. Szczegółowe dane zawartości harmonicznych prądu THDi przedstawione na rys. 8 zawierają się $\mathrm{w}$ granicach od 22,8 do 25,8 [\%]. Wartości harmonicznych prądu uzyskane z pomiarów porównano ze standardem IEEE 519 [1], które przedstawiono $\mathrm{w}$ tabl. 1. W celu ograniczenia negatywnego wpływu harmonicznych odbiorników nieliniowych, szczególnie dla spełnienia wymagań wg IEEE-519 [1], należy zastosować dodatkowe filtry lub inne układy do kompensacji mocy odkształconej. Innym sposobem zmniejszania zawartości harmonicznych jest wymiana zespołów prostownikowych na prostowniki ze zwiększoną liczbą pulsów np. z 6 na 12. Powoduje to znaczny wzrost kosztów budowy układu zasilania, lecz jest to niezbędne w celu zapewnienia zmniejszenia strat energii elektrycznej oraz zmniejszenia prawdopodobieństwa uszkodzeń szczególnie wrażliwych odbiorców energii elektrycznej, tabela 2 i 3. 
Tabela 1. Wykaz dopuszczalnych poziomów zawartości harmonicznych nieparzystych prądu wg IEEE-519

Table 1. List of permissible levels of harmonic content of odd currents according to IEEE-519

\begin{tabular}{|c|c|c|c|c|c|}
\hline Izw/Iobc & $<\mathbf{2 0}$ & $\mathbf{2 0 . . 5 0}$ & $\mathbf{5 0 . . 1 0 0}$ & $\mathbf{1 0 0} \ldots \mathbf{1 0 0 0}$ & $\mathbf{> 1 0 0 0}$ \\
\hline $\begin{array}{c}\text { THDi dla } \\
\text { n }<11\end{array}$ & $4 \%$ & $7 \%$ & $10 \%$ & $12 \%$ & $15 \%$ \\
\hline THDi & $5 \%$ & $8 \%$ & $12 \%$ & $15 \%$ & $20 \%$ \\
\hline
\end{tabular}

W tabeli 1 dla standardu IEEE-519 [1] podano wykaz dopuszczalnych poziomów zawartości harmonicznych nieparzystych prądu dla nieliniowych obciążeń w sieciach TN, które współpracują z innymi obciążeniami o napięciach od $120 \mathrm{~V}$ do $69000 \mathrm{~V}$.

Tab. 2. Wykaz dopuszczalnych poziomów zawartości harmonicznych napięcia wg IEEE-519.

Table 2. Permissible levels of harmonic voltage levels according to IEEE-519.

\begin{tabular}{|c|c|}
\hline Wrażliwości odbiorów & THDu (\%) \\
\hline Bardzo wrażliwe: lotniska , szpitale & $3 \%$ \\
\hline Średnio wrażliwe: Szkoły, biura & $5 \%$ \\
\hline Mało wrażliwe: Fabryki & $10 \%$ \\
\hline
\end{tabular}

Tab. 3. Wykaz dopuszczalnych poziomów zawartości harmonicznych napięcia THDu w/g różnych norm

Table 3. List of permissible harmonic levels of THD voltage in various standards

\begin{tabular}{|c|c|c|}
\hline & THDu & $\begin{array}{c}\text { Zawartość pojedynczej harmonicznej } \\
\left(\mathbf{U}_{\mathbf{n}} / \mathbf{U}_{\mathbf{1}}\right) \mathbf{x} \mathbf{1 0 0 \%}\end{array}$ \\
\hline IEEE-519 & $5 \%$ & $3 \%$ \\
\hline PN-EN 50160 & $8 \%$ & $1,5-6 \%$ \\
\hline
\end{tabular}

Po analizie zawartości wyższych harmonicznych napięcia oraz prądu można stwierdzić, że wyższe harmoniczne powinny zawierać się w zakresach podanych w tabeli 3 (dodatkowe informacje o poziomach zawartości harmonicznych podano w tabelach 1 i 2). Zwiększona ilość wyższych harmonicznych, szczególnie ponad dopuszczalne wartości określone w dokumentach normatywnych, powoduje bardzo negatywny wpływ na jakość energii elektrycznej i jest bezpośrednim powodem uszkodzenia innych odbiorników, przegrzewania się transformatorów oraz uszkodzeń kabli zasilających. Na podstawie analizy rys. 5 i 7 widać, iż w trakcie pobierania energii elektrycznej z sieci przez podstację trakcyjną prąd jest niesinusoidalny. Odkształcony prąd rozłożono na składowe przedstawione na rys. 6. Składowe te są prądami o częstotliwościach będących wielokrotnością częstotliwości podstawowej. Częstotliwości te są nazywane wyższymi harmonicznymi, które przedstawione na rys. 6 i 10, wskazują wpływ prostownika 6-cio pulsowego jako przyczynę pojawiania się harmonicznych charakterystycznych prądu. 


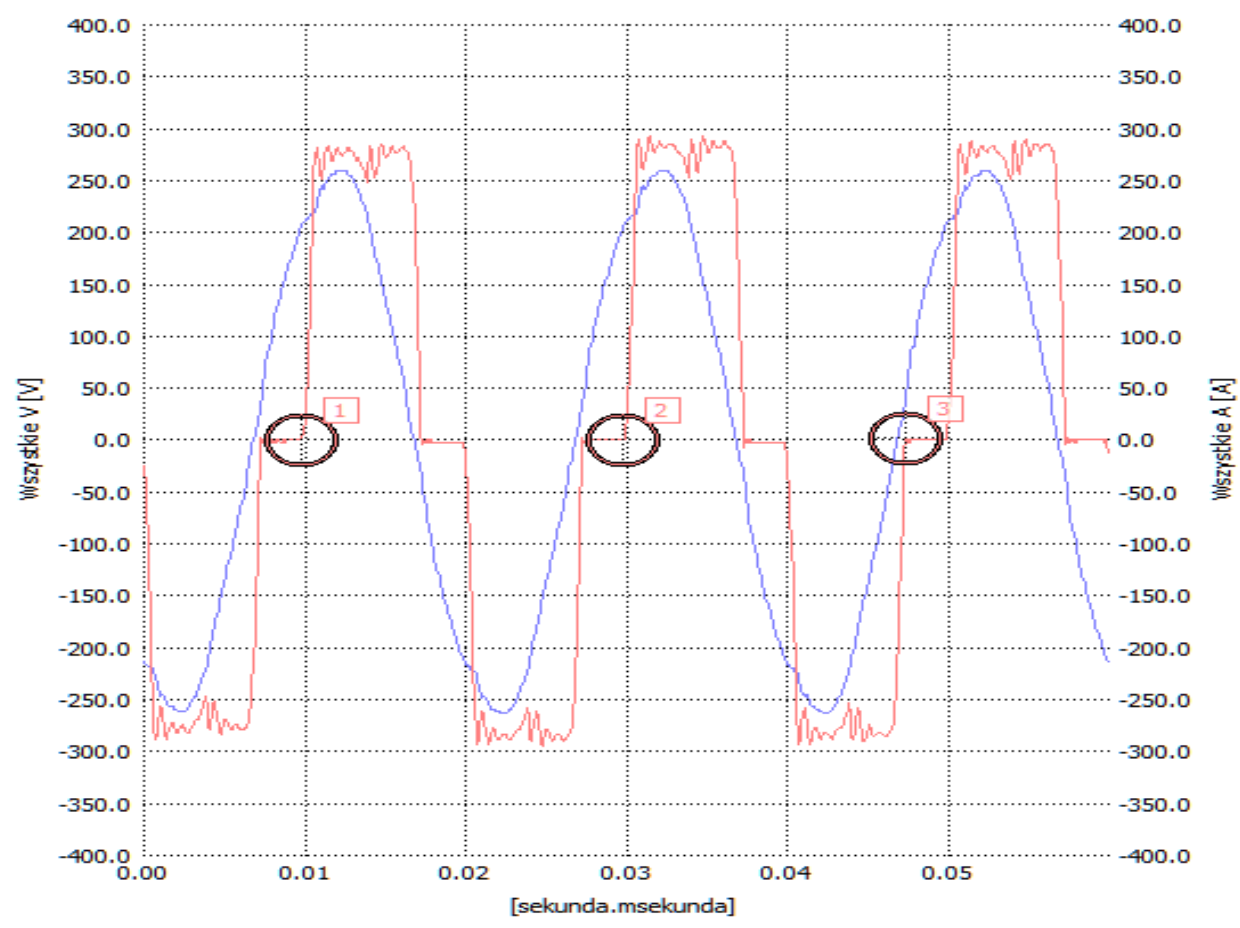

Rys. 5. Przebieg napięcia i prądu na linii zasilającej $20 \mathrm{kV}$ (pomiar 1). Przebieg prądu - kolor czerwony. Przebieg napięcia - kolor niebieski

Fig 5. Voltage and current waveform on the $20 \mathrm{kV}$ power line (measurement 1). Current wave red. Voltage range - blue

W trakcie poboru energii elektrycznej przez odbiorniki dużej mocy pojawiają się również w sieci zasilającej odkształcenia napięcia. W tym przypadku każdy przyłączony do tej sieci odbiorca będzie zasilany zniekształconym napięciem, na co dystrybutor energii elektrycznej bezwzględnie musi zwracać uwagę $[4,6,7]$. Urządzenia kolejowe, szczególnie te, od których zależy bezpieczeństwo prowadzenia ruchu pociągów, muszą być bezwzględnie zasilane energią elektryczną o właściwych parametrach [11].

W podstacjach trakcyjnych dla poprawy jakości energii elektrycznej stosuje się standardowo urządzenia wygładzające. Wyższe harmoniczne prądu i napięcia, występujące po obydwu stronach zespołu prostownikowego, wywierają szkodliwe oddziaływania na inne urządzenia lub linie np. telekomunikacyjne. 


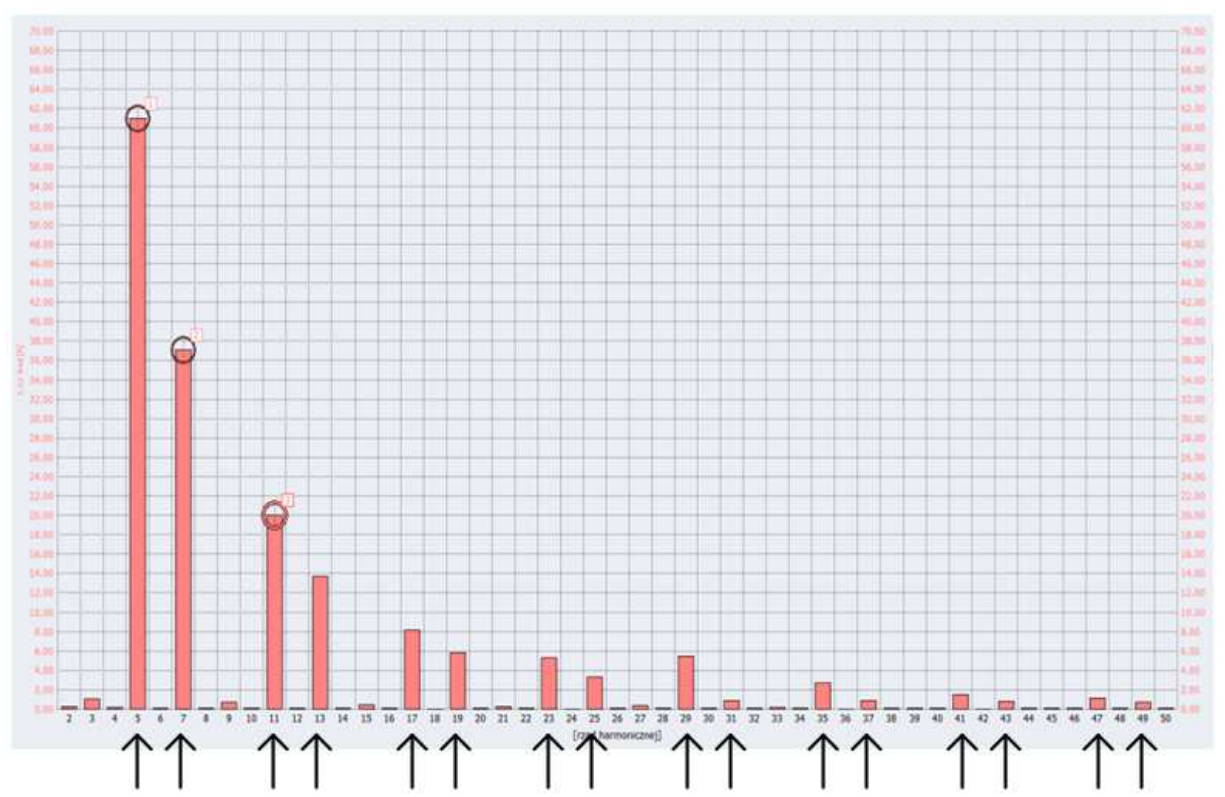

Rys. 6. Wartości wyższych harmonicznych (pomiar 1). $\uparrow$ - oznaczenie harmonicznych charakterystycznych

Fig 6. Higher Harmonic Values (Measurement 1). $\uparrow$ - characterization of harmonics

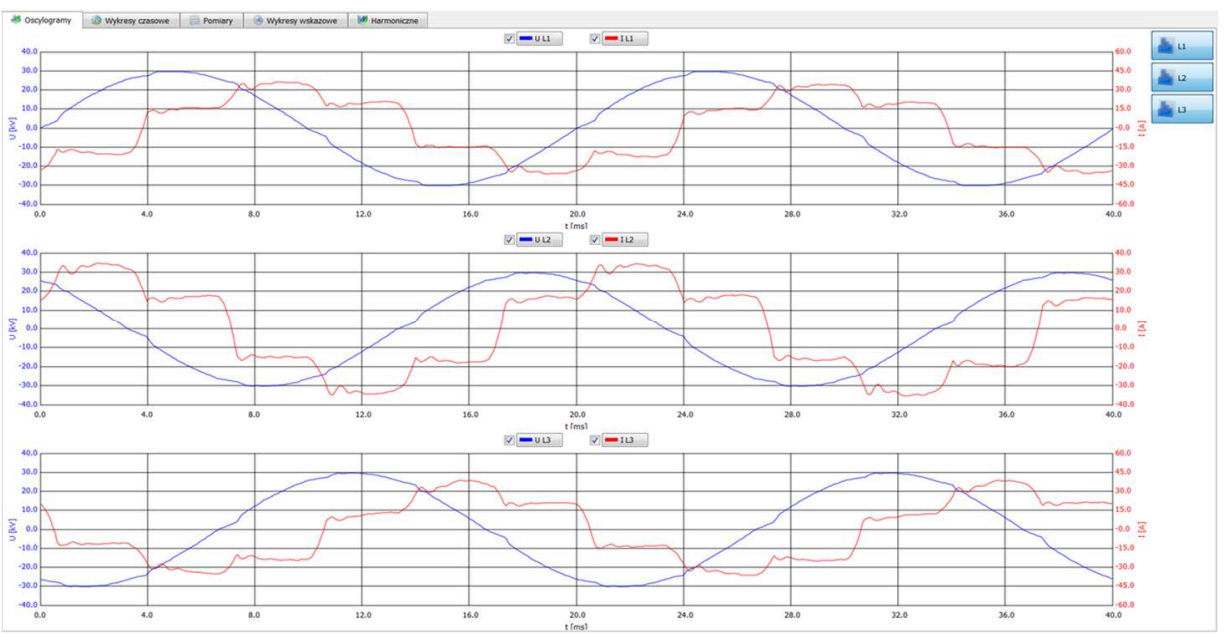

Rys. 7. Zarejestrowane przebiegi napięcia i prądu zespołu prostownikowego w podstacji trakcyjnej (pomiar 2)

Fig 7. Recorded voltage and current flows of rectifier unit in traction substation (measurement 2) 
Dla zakłóceń przekazywanych do sieci trakcyjnej po stronie rozdzielni prądu stałego stosuje się urządzenia wygładzające. Zwykle są to rezonansowe urządzenia wygładzające (LC) z członem aperiodycznym (C). Urządzenia wygładzające współpracują z bezrdzeniowym dławikiem, który o stałej, niezależnej od prądu indukcyjności, włączony jest szeregowo w tor prądowy z reguły o biegunowości dodatniej, za zespołem prostownikowym. W przypadku uszkodzenia elementów mających za zadanie poprawę jakości energii elektrycznej na podstacji trakcyjnej, tzw. „urządzenia wygładzające”, może wystąpić pogorszenie jakości energii elektrycznej. Powodem uszkodzenia elementów urządzeń wygładzających może być wpływ wyższych harmonicznych na kondensatory. Fakt ten wynika z fizycznych właściwości kondensatora tzn. jego reaktancji.

Kondensator, którego opór bierny pojemnościowy jest odwrotnie proporcjonalny do częstotliwości harmonicznej prądu przepływającego przez niego, powoduje iż dla każdej wyższej częstotliwości harmonicznej jego reaktancja znacząco maleje. Na skutek przeciążenia kondensatorów prądami większymi od wartości prądu wskazanego na tabliczce znamionowej następuje ich uszkodzenie. Powodem takiego zjawiska jest $m$. in. wpływ zespołów prostownikowych oraz odbiorników podłączonych do podstacji trakcyjnej. Pomiary zostały wykonane analizatorem jakości zasilania PQM-701Z.

Na rysunku 8 przedstawiono zarejestrowane przebiegi THD I L-1 od wartości $22,83 \%$ do wartości $25,83 \%$.

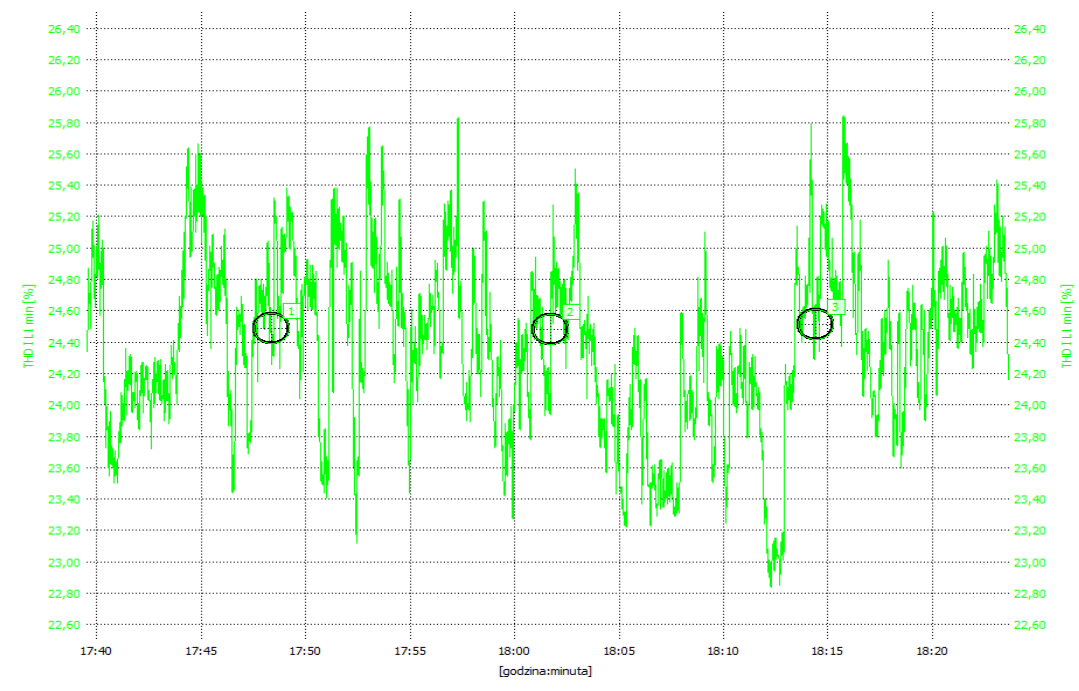

Rys. 8. Zarejestrowane przebiegi THD I L-1 (pomiar 2) w podstacji trakcyjnej

Fig 8. Recorded THD and L-1 waveforms (measurement 2) in the traction substation 
Na rysunku 9 przedstawiono zarejestrowane przebiegi I L-1 od wartości 15,90 A do wartości 50,40 A.

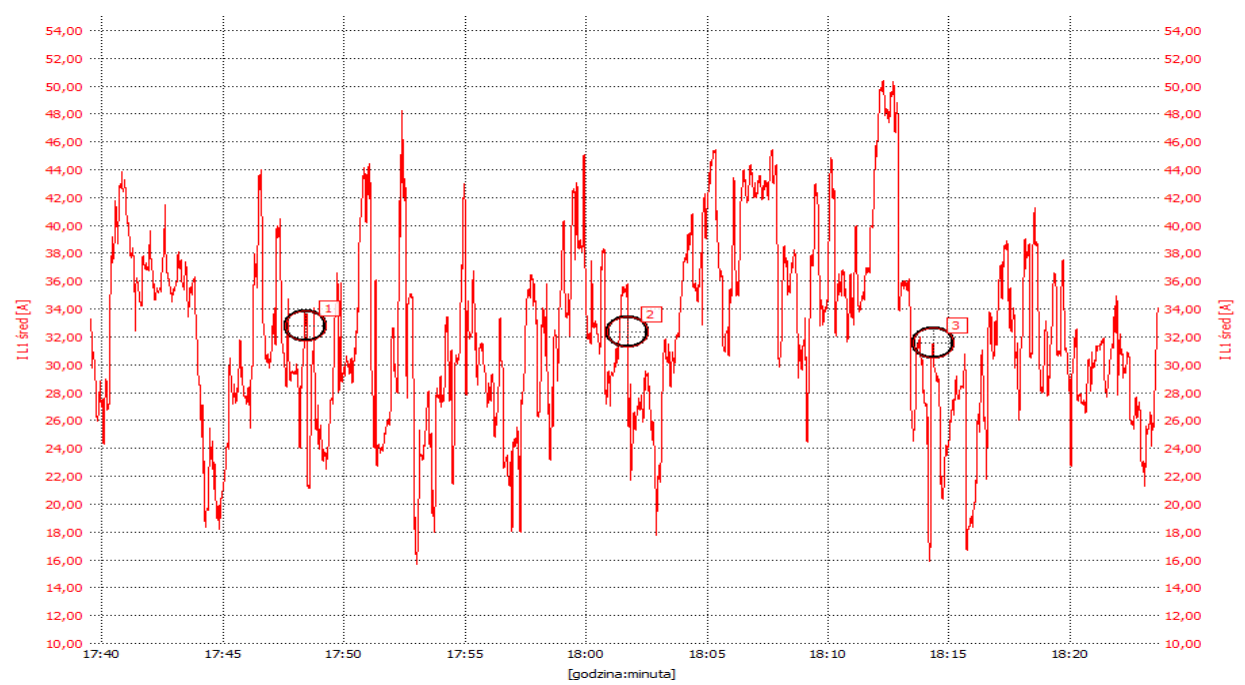

Rys. 9. Zarejestrowane przebiegi I L-1 (pomiar 2) w podstacji trakcyjnej

Fig 9. Recorded I L-1 (measurement 2) in the traction substation

Na rys. $\mathrm{nr} 10$ przedstawiono zarejestrowane przebiegi $\mathrm{I}_{\mathrm{H}} \mathrm{L}-1$. Harmoniczne charakterystyczne dla prostownika 6-cio pulsowego.

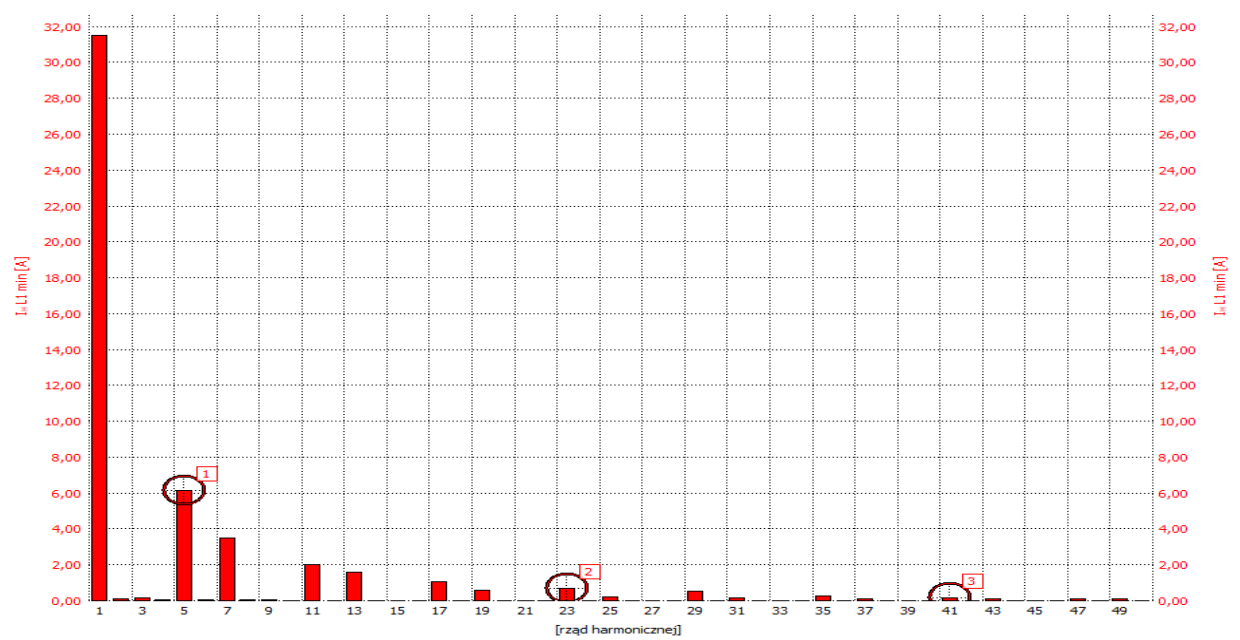

Rys. 10. Zarejestrowane przebiegi $\mathrm{I}_{\mathrm{H}} \mathrm{L}-1$ (pomiar 2) w podstacji trakcyjnej.

Fig 10. Recorded IH L-1 waveforms (measurement 2) in the traction substation. 


\section{Wnioski}

Zasilanie urządzeń energetyki trakcyjnej oraz nietrakcyjnej na terenie PKP Polskie Linie Kolejowe S.A. jest realizowane poprzez podstacje trakcyjne. W celu zapewnienia bezpiecznego prowadzenia ruchu kolejowego należy spełnić wymagania dotyczące jakości energii elektrycznej. Urządzenia energetyki nietrakcyjnej zasilane są z rozdzielni prądu przemiennego podstacji trakcyjnej, a zasilanie sieci trakcyjnej po transformacji napięcia przemiennego na napięcie stałe odbywa się poprzez transformatory oraz zespoły prostownikowe podstacji trakcyjnej. W takich zespołach prostownikowych efektem niepożądanym jest pojawianie się wyższych harmonicznych napięcia oraz prądu. Harmoniczne te przenoszą się do dostawcy energii elektrycznej poprzez linie zasilające podstację trakcyjną. Dodatkowo odbiorcy energii elektrycznej przyłączeni do LPN (linii potrzeb nietrakcyjnych) oraz pojazdy trakcyjne zasilane (poprzez sieć trakcyjną) z podstacji trakcyjnej również są narażeni na negatywne oddziaływanie wyższych harmonicznych na swoje urządzenia. W celu zmniejszania negatywnego oddziaływania wyższych harmonicznych stosuje się dławiki, filtry pasywne rezonansowe oraz aktywne. Działania te są niezbędne, aby współczynnik zawartości wyższych harmonicznych napięcia i prądu (THD) nie powodował szkodliwego oddziaływania na sieć energetyczną oraz odbiory podłączone do nich.

W podstacjach trakcyjnych często występują uszkodzenia urządzeń wygładzających. Pomiary jakości energii elektrycznej zostały wykonane na podstacji trakcyjnej, gdzie urządzenie wygładzające zostało odłączone przez obsługę z powodu uszkodzenia. Pomiary jakości energii elektrycznej wykazały bardzo znaczne przekroczenie poziomów normatywnych zawartości wyższych harmonicznych.

\section{Literatura}

[1] IEEE Recommended Practice and Requirements for Harmonic Control in Electric Power Systems. IEEE Std 519-2014.

[2] IEEE Standard Definitions for the Measurement of Electric Power Quantities Under Sinusoidial, Nonsiunusoidal, Balanced, or Unbalanced Conditions, IEEE 14592010

[3] Hanzelka Z.: Jakość energii elektrycznej. Część 4. Wyższe harmoniczne napięć i prądów.

[4] Ustawa z dnia 10 kwietnia 1997r. z późniejszymi zmianami Prawo energetyczne Dz.U. z 2012r., poz. 1059. Z 2013r., poz. 984 i poz.1238, z 2014r., poz. 457, poz. 490, poz. 900, poz. 942, poz. 11010, poz. 1662 oraz z 2015r. poz. 151, poz. 478 i poz. 942.

[5] Rozporządzenie Ministra Gospodarki z 4 maja 2007 r. w sprawie szczegółowych zasad funkcjonowania systemu elektroenergetycznego (Dz. U. z 2007 r. Nr 93, poz. 623, z późn. zm.) s. 5665-5668. 
[6] PN-EN 50121-2: 2004. Zastosowania kolejowe. Kompatybilność elektromagnetyczna. Część 2: Oddziaływanie systemu kolejowego na otoczenie.

[7] Standardy techniczne - szczegółowe warunki techniczne dla modernizacji lub budowy linii kolejowych do prędkości $V \max \leq 200 \mathrm{~km} / \mathrm{h}$ (dla taboru konwencjonalnego) $/ 250 \mathrm{~km} / \mathrm{h}$ (dla taboru z wychylnym pudłem). Warszawa 2009.

[8] PN-EN 61000-3-2 Kompatybilność elektromagnetyczna (EMC) - Część 3-2: Poziomy dopuszczalne - Poziomy dopuszczalne emisji harmonicznych prądu (fazowy prąd zasilający odbiornika $\leq 16 \mathrm{~A}$ ).

[9] PN-EN 61000-3-12 Kompatybilność elektromagnetyczna (EMC) - Część 3-12: Dopuszczalne poziomy - Dopuszczalne poziomy harmonicznych prądów powodowanych działaniem odbiorników, które mają być przyłączone do publicznej sieci zasilającej niskiego napięcia $\mathrm{z}$ fazowym prądem zasilającym odbiornika > $16 \mathrm{~A}$ $\mathrm{i} \leq 75 \mathrm{~A}$.

[10] PN-EN 50160:2010 Parametry napięcia zasilającego w publicznych się ciach elektroenergetycznych s.13.

[11] Żelazny R.: Urządzenia elektrycznego ogrzewania rozjazdów oraz oświetlenia zewnętrznego na terenie PKP Polskie Linie Kolejowe S.A. ZESZYTY NAUKOWE Politechniki Rzeszowskiej. Tom XXV zeszyt 36 (nr 2/2017).

\section{QUALITY OF ELECTRICITY IN POWER LINES FOR RECEIVERS PKP POLISH RAILWAY LINES S.A.}

\section{S u m m a r y}

The article presents definitions resulting from current legal and technical conditions. Problems related to the quality of electric power in traction substations during emergency operation are also presented. The emergency condition causes irregularities which result in disturbances being introduced into the supply network and loads supplied from traction substations. In addition, the influence of the occurrence of current harmonics on the operation of selected electricity reflections as well as the methods of its reduction are presented. The basic requirements regarding the quality of electricity in PKP Polish Railway Lines S.A. were mentioned.

Keywords: Traction substation, higher current harmonics, rectifier unit.

DOI: $10.7862 /$ re. 2018.3

Tekst złożono w redakcji: grudzień 2017

Przyjęto do druku: grudzień 2017 